\title{
SYNTHESIS AND CYTOTOXIC ACTIVITY OF CHALCONE DERIVATIVES ON HUMAN BREAST CANCER CELL LINES
}

\author{
Nuraini Harmastuti ${ }^{1,{ }^{*}}$, Rina Herowati ${ }^{1}$, Dyah Susilowati ${ }^{1}$, \\ Harno Dwi Pranowo ${ }^{2}$, and Sofia Mubarika ${ }^{3}$ \\ ${ }^{1}$ Faculty of Pharmacy, Universitas Setia Budi, Jl. Letjen Sutoyo, Surakarta, Indonesia 57127 \\ ${ }^{2}$ Faculty of Mathematics and Natural Sciences, Universitas Gadjah Mada, Sekip Utara, Yogyakarta, Indonesia, 55281 \\ ${ }^{3}$ Faculty of Medicine, Universitas Gadjah Mada, Jl. Farmako, Sekip Utara, Yogyakarta, Indonesia, 55281
}

Received February 3, 2012; Accepted November 6, 2012

\begin{abstract}
Chalcone, an $\alpha, \beta$-unsaturated ketone, has been shown have many biological activities such as anticancer and antifungi. This research was conducted to synthesize the chalcone derivatives and to obtain their cytotoxic activity on human cervix cancer cell lines. Synthesis of chalcone and its derivatives, 4"-methylchalcone, $4^{\prime \prime}$-methoxychalcone, and $3^{\prime \prime}, 4^{\prime \prime}$-dichlorochalcone was carried out using starting materials of benzaldehide and acetofenon, $p$-methylacetophenone, $p$-methoxyacetophenone, as well as m,p-dichloroacetophenone through Claisen Schmidt condensation catalized by $\mathrm{NaOH}$ in ethanol at $15{ }^{\circ} \mathrm{C}$. The purity of synthesized compounds were analyzed by thin layer chromatography, melting range, and gas chromatography. Structure elucidations were conducted by UV spectrophotometer, IR spectrometer, ${ }^{1} \mathrm{H}-\mathrm{NMR}$ spectrometer, as well as mass spectrometer. Cytotoxic activities were determined by 3-[4,5-dimethylthiazol-2-yl]-2,5-diphenyltetrazolium bromide (MTT) microculture tetrazolium viability assay. The results showed that chalcone and derivatives compounds have been able to be synthesized and purified and had the same structure as a predicted structure. Chalcone had highest cytotoxic activity compared to that of its derivatives, with the $I C_{50}$ values of chalcone, $4^{\prime \prime}$-methylchalcone, $4^{\prime \prime}$-methoxychalcone, and $3^{\prime \prime}, 4^{\prime \prime}$-dichlorochalcone were $9.49,14.79,11.48$, and $24.26 \mu \mathrm{g} / \mathrm{mL}$ respectively. It was concluded that methyl, methoxy as well as chlorine substitution at $3^{\prime \prime}$ and $4^{\prime \prime}$ position decrease the cytotoxic activity of chalcone.
\end{abstract}

Keywords: chalcone derivatives; synthesis; MTT; cytotoxic; HeLa cell lines

\section{ABSTRAK}

Kalkon, a,ß-tidak jenuh karbonil keton telah menunjukkan mempunyai bermacam-macam aktivitas biologi, diantaranya sebagai antikanker dan antifungi. Penelitian ini bertujuan untuk mensintesis turunan kalkon dan mengamati aktivitas sitotoksiknya pada sel turunan kanker leher rahim. Sintesis kalkon dan turunannya, $4^{\prime \prime}$-metilkalkon, 4"-metoksikalkon, dan $3^{\prime \prime}, 4^{\prime \prime}$-diklorokalkon dilakukan menggunakan material awal dari benzaldehida dan asetofenon, $p$-metilasetofenon, p-metoksiasetofenon, serta m,p-dikloroasetofenon melalui kondensasi Claisen Schmidt yang dikatalisis oleh $\mathrm{NaOH}$ dalam etanol pada temperatur $15{ }^{\circ} \mathrm{C}$. Kemurnian senyawa hasil sintesis dianalisis dengan kromatografi lapis tipis, titik lebur, dan kromatografi gas. Elusidasi struktur dianalisis menggunakan spektrofotometer UV, spektrometer IR, spektrometer $H^{1}$-NMR, serta spektrometer massa. Aktivitas sitotoksik ditentukan dengan uji viabilitas menggunakan 3-[4,5-dimethylthiazol-2-yl]-2,5-diphenyltetrazolium bromide (MTT). Hasil penelitian menunjukkan bahwa kalkon dan senyawa-senyawa turunannya telah dapat disintesis, dimurnikan, dan mempunyai struktur kimia sesuai yang diperkirakan. Kalkon mempunyai aktivitas sitotoksik paling tinggi dibandingkan turunan-turunannya, dengan harga $I C_{50}$ dari kalkon, $4^{\prime \prime}$-metilkalkon, $4^{\prime \prime}$-metoksikalkon, dan $3^{\prime \prime}, 4^{\prime \prime}$ diklorokalkon berturut-turut adalah 9,49, 14,79, 11,48, dan 24,26 $\mu \mathrm{g} / \mathrm{mL}$. Disimpulkan bahwa substitusi metil, metoksi serta klorin pada posisi $3^{\prime \prime}$ dan $4^{\prime \prime}$ menurunkan aktivitas sitotoksik dari kalkon.

Kata Kunci: turunan kalkon; sintesis; MTT; sitotoksik; sel HeLa

\section{INTRODUCTION}

Among the $\alpha$, $\beta$-unsaturated carbonyl ketones, chalcones is small-molecule aromatic enone analogue of curcumin. Pharmacophore model of chalcone has divided into three regions (Fig. 1). Region $A$ requires an aromatic ring, region $B$ is composed of an enone, and region $\mathrm{C}$ requires an aromatic ring, too. A rational

* Corresponding author. Tel/Fax : +62-8886753263

Email address : nuraini_harmastuti@yahoo.co.id

Nuraini Harmastuti et al. 
approach following standard medicinal chemistry design concepts was to explore compounds with systematic differences in carbon chain connecting the two aromatic regions [1].

Chalcone is an aromatic ketone which forms the central core for a variety of important biological compounds [2]. Chalcones have been reported to have a wide variety of biological activities, such as antimicrobial [3], anticancer, antioxidant and anti-inflammatory [4-5]. Some chalcones showed the ability to block voltagedependent potassium channels [6]. Chalcones also potentially inhibit the NF-KB pathway. Nuclear factor (NF)-KB is a mediator of inflammatory diseases and cancer and has been shown to induce resistance to various chemotherapeutic agents. The reduction of the alkene into a single bond completely attenuates their inhibition potential [7]. A number of $\alpha, \beta$-unsaturated carbonyl ketones (2-propen-1-one) which are associated with various alkilating agents used in cancer chemotherapy. The antitumor activity, suggesting that the effect can be in the electron transporting chain. One of the electrophilic sites in the chalcone moiety can be found at the C3 carbon atom of the 2-propen-1-one moiety [8].
Utami [9] had synthesized chalcone and its derivates based on Vogel method [10] by modifications of electron donating group and electron withdrawing group to $\mathrm{C}-4$ ' of aromatic ring attached to $\alpha$, $\beta$-unsaturated carbonyl ketones. This chalcone compound had cytotoxic activity on HeLa cell line. Horng-Huey Ko [11] reported the increasing of lipophilicity of the chalcones after introduction of a lipophilic alkyl group at the aromatic ring which directly attached to the keton carbonyl. These increasing significantly enhanced the inhibitory effects on NO production in macrophages, the important mediator in inflammatory process. The chalcone and its derivatives were synthesized by modifying a substituent group i.e. methyl, methoxy, and chloro at the $4^{11}$ position in the aromatic ring directly attached to the keton carbonyl. The introduction of an substituent group in the aromatic<smiles></smiles>

Fig 1. Pharmacophore model of chalcone<smiles>[R]c1ccc(C(=O)/C=C/c2ccccc2)cc1[R]</smiles><smiles>[R]c1ccc(C(=O)[C@@H](C)[C@]([2H])(O)c2ccccc2)cc1[R]</smiles>

Chalcone and its derivative The target molecule

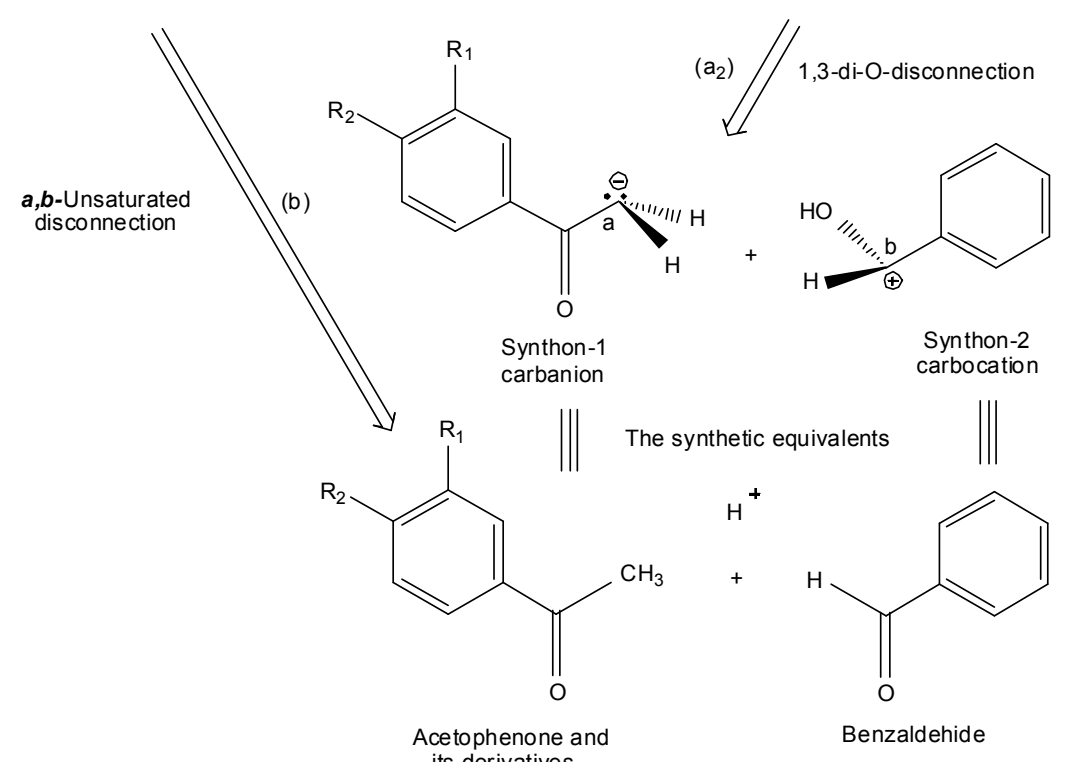

its derivatives

Fig 2. The disconnection of chalcone and its derivatives 
C-ring (Fig. 1) of chalcone increased the lipophilicity.

This research was conducted to synthesize the chalcone derivatives and to obtain their cytotoxic activity on human breast cancer cell lines. The design of synthesis of chalcone and its derivatives, 4"-methyl chalcone, $4^{\prime \prime}$-methoxychalcone, and $3^{\prime \prime}, 4^{\prime \prime}$-dichloro chalcone could be approached by disconnection Stuard Waren method. This method illustrates the planing of synthesis would be carried out. It was started from the target molecule and break down by a series of disconnections into possible starting materials. Based on those analysis (Fig. 2), the synthesis of chalcone and its derivatives, 4"-methylchalcone, 4"-methoxychalcone, and $3^{11}, 4^{\prime \prime}$-dichlorochalcone could be carried out using benzaldehide, acetophenone and acetophenone derivatives, p-methylacetophenone, p-methoxy acetophenone, as well as $\mathrm{m}, \mathrm{p}$-dichloroacetophenone as starting materials.

In this, study chalcone and its derivatives, 4"-methylchalcone, 4"-methoxychalcone, and $3^{\prime \prime}, 4^{\prime \prime}$-dichlorochalcone, were synthesized by the alkaline Claisen-Schmidt condensation of acetophenone (1), p-methyl acetophenone (2), p-methoxyacetophenone (3), m,p-dichloroacetophenone (4), and benzaldehide. Chalcone and its derivatives then were determined their cytotoxic activity by 3-[4,5-dimethylthiazol-2-yl]-2,5diphenyltetrazolium bromide (MTT) microculture tetrazolium viability assay.

\section{EXPERIMENTAL SECTION}

\section{Materials}

Benzaldehide $\quad 97 \% \quad$ (Janssen Chimica), acetophenone $98 \%$ (E-Merck), p-methylacetophenone, $\mathrm{p}$-methoxyacetophenone, m,p-dichloroacetophenone (Molnas Laboratory of Universitas Gadjah Mada), ethyl alcohol 96\% (E-Merck); sodium hydroxide $(\mathrm{NaOH})$ (E-Merck), litmus paper (Sigma), ice solid, aquades, chloroform (E. Merck), n-hexane (E-Merck), methanol (E-Merck), ethyl acetate (E-Merck), fillter paper. HeLa cell line, RPMI 1640 powder (GIBCO), growth medium contain growth factor 10\% FBS (Fetal Bovine Serum) $-0.5 \%$ fungison $-2 \%$ penicillin and streptomycin (GIBCO) and RPMI 1640 medium, DMSO, sodium bicarbonate p.a. (Sigma), MTT (3-[4,5-Dimethylthiazol-2yl]-2,5-diphenyltetrazolium Bromide), Phosphate Buffer Saline, solution $10 \%$ of sodium dodecyl sulphate (SDS) in $\mathrm{HCl} 0.01 \mathrm{~N}$, primer antibody p53 and cyclooxygenase-2 (COX-2).

\section{Instrumentation}

A set of glassware for synthesis, the analytical balance Meltler AT-200, thermometer, stirrer $3 \mathrm{~cm}$,
Termopan (Reichert Austria, Nr. 340 579), thin layer chromatography (TLC) silica gel GF254 (E-Merck), ultraviolet lamp $254 \mathrm{~nm}$ and $366 \mathrm{~nm}$, Buchi Melting Point B-540, the UV-Vis spectrum were recorded on Spectronic 3000 Array Milton Roy, the IR spectrum were recorded on Shimadzhu FTIR-8201 PC, the $\mathrm{H}$-magnetic resonance spectrum were performed using JNM-MY $60 \mathrm{JEOL}$ in $\mathrm{CDCl}_{3}$, the mass spectrum were recorded using GCMS-QP2010S SHIMADZU with Rtx-5MS column (length $30 \mathrm{~m}$; ID $0,25 \mathrm{~mm}$; column Oven Temperature: $150{ }^{\circ} \mathrm{C}$; injection Temperature: $320{ }^{\circ} \mathrm{C}$ ), Helium as moblie gas, El ionization, Oven temperature was set from $150{ }^{\circ} \mathrm{C}$ (hold time $5 \mathrm{~min}$ ), temperature increasing of $10^{\circ} \mathrm{C} / \mathrm{min}$ to achieve $290{ }^{\circ} \mathrm{C}$ (hold time was $31 \mathrm{~min}$ ). Liquid nitrogen tank, centrifuge Sigma $3 \mathrm{~K} 12$ (B. Braun Biotech International), $\mathrm{CO}_{2}$ Incubator (Nuaire ${ }^{\mathrm{TM}}$ IR autoflow), Laminar Air Flow Cabinet (Nuaire), ELISA reader (SLT 240 ATC), sterile conical flask (Nunclone), tissue culture flask (Nunclone), microplate 96 weels, electrical balance (Sartorius), micropipette, vortex.

\section{Procedure}

\section{Synthesis of chalcone derivatives}

Chalcone and its derivatives were prepared by adding $\mathrm{NaOH}$ solution $(0.014 \mathrm{~mol} ; 0.56 \mathrm{~g}$ in $3.75 \mathrm{~mL}$ of water) to an equimolar aldehyde $(0.005 \mathrm{~mol})$ and ketone $(0.005 \mathrm{~mol})$ solution in ethyl alcohol. The reaction mixture was stirred at about $15{ }^{\circ} \mathrm{C}$ for $3 \mathrm{~h}$ with constant stirring. The stirrer was removed and the reaction mixture was left in the refrigerator at $15^{\circ} \mathrm{C}$ for $24 \mathrm{~h}$. The yellow precipitate then was collected by vacuum filtration, washed with cold water until neutral to litmus, and the precipitate was washed with $6 \mathrm{~mL}$ of cold ethyl alcohol and dried in the air. The products were purified by recrystallization from ethyl alcohol. Structure elucidations were conducted by UV spectrophotometer, ${ }^{1} \mathrm{H}$-NMR spectrometer, IR spectrometer, as well as mass spectrometer. The stuctures of the products were shown in Fig. 3.

\section{Cytotoxic test}

Cytotoxic activity was determined with 3-[4,5-dimethylthiazol-2-yl]-2,5-diphenyltetrazolium bromide (MTT) microculture tetrazolium viability assay.

Cell culture preparation. Human cervical cancer cell line (HeLa cell line) was grown in RPMI medium in tissue culture flask. The supernatan was transfered to sterile conical flask, and was centrifuged $(700 \mathrm{rpm} \times$ $10 \mathrm{~min}$ ). The supernatan was removed, and $1 \mathrm{~mL}$ of growth medium in PBS 10\% was added to the pellet part, and slowly resuspended. Ten $\mu \mathrm{L}$ of cell suspension was diluted in PBS $10 \%$, and the cell count was determined using hemocytometer. Cell count in 


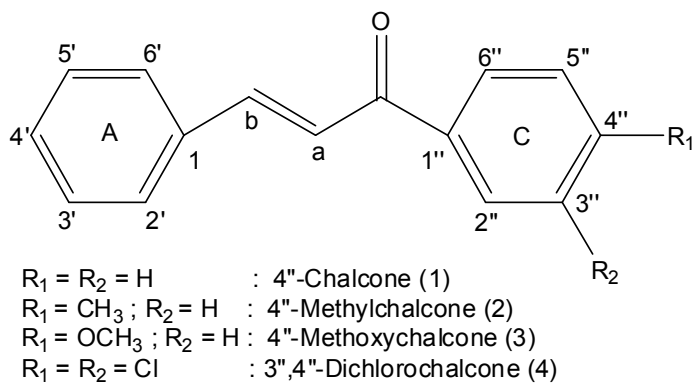

Fig 3. Structure of chalcone and its derivatives

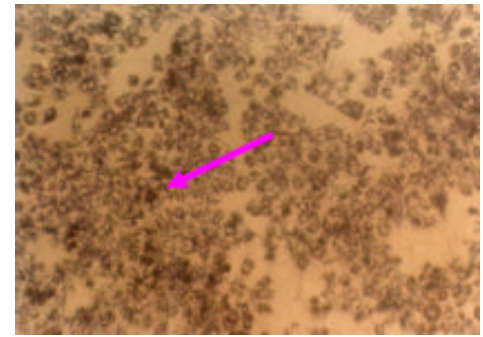

Fig 5. Photomicroscopy of formazan formation by MTT method. ( $\longrightarrow$ = formazan)

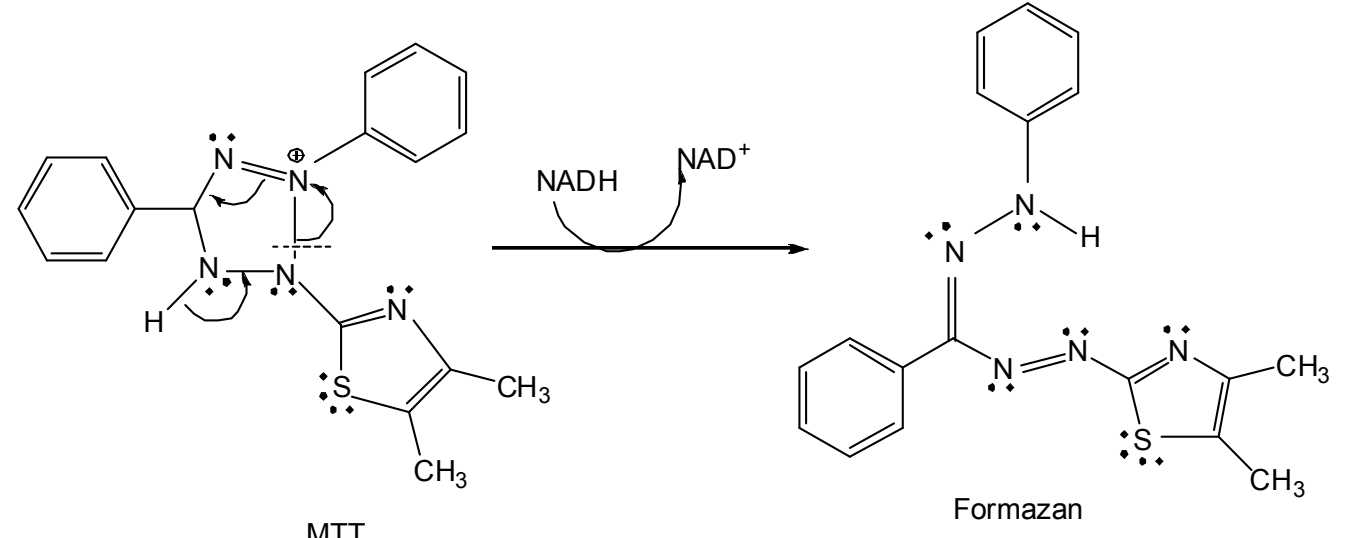

MTT

Fig 4. Reduction of MTT to Formazan

suspension was adjusted by dilution.

Preparation of test compounds solution. One $\mathrm{mL}$ of stock solution of $p$-metoxychalcone and its derivatives in DMSO pro culture were made in concentration of $5000 \mu \mathrm{M}$. The stock solution was diluted to obtain concentrations of $100 \mu \mathrm{g} / \mathrm{mL}, 50 \mu \mathrm{g} / \mathrm{mL}, 25 \mu \mathrm{g} / \mathrm{mL}$, $12.5 \mu \mathrm{g} / \mathrm{mL}, 6.25 \mu \mathrm{g} / \mathrm{mL}$, as well as $3.125 \mu \mathrm{g} / \mathrm{mL}$. The stock solution preparation and test solution dilution were conducted in laminar air flow cabinet.

MTT assay. The cells were seeded at a concentration of $3 \times 10^{4}$ cells/well in $100 \mu \mathrm{L}$ culture medium and incubated at $37{ }^{\circ} \mathrm{C}$ in $5 \% \mathrm{CO}_{2}$ incubator for $24 \mathrm{~h}$, then $100 \mu \mathrm{L}$ of different concentrations of test compound was added. The microplates were kept for incubation at $37{ }^{\circ} \mathrm{C}$ in $5 \%$ $\mathrm{CO}_{2}$ incubator for $24 \mathrm{~h}$ and cells were periodically checked for granularity, shrinkage, swelling. After $24 \mathrm{~h}$, the sample solution in wells was flicked off and $10 \mu \mathrm{L}$ of MTT dye was added to each well. The plates were gently shaken and incubated for $4 \mathrm{~h}$ at $37^{\circ} \mathrm{C}$ in $5 \% \mathrm{CO}_{2}$ incubator. Live cells would react with MTT to produce violet color of formazan. The supernatant was removed and $100 \mu \mathrm{L}$ of SDS $10 \%$ in $0.01 \mathrm{~N} \mathrm{HCl}$ was added and the plates were gently shaken to solubilize the formed formazan. The mixtures were incubated for $24 \mathrm{~h}$ at room temperature. The absorbance was measured using a microplate reader at $550 \mathrm{~nm}$. Positif control test was conducted without test compound, while blank test was conducted for the solvent without test compound.

\section{RESULT AND DISCUSSION}

\section{Synthesis of Chalcone Derivatives}

Synthesis of chalcone and its derivatives, 4"-methylchalcone, 4"-methoxychalcone, and $3^{\prime \prime}, 4^{\prime \prime}$-dichlorochalcone, using the Claisen-Schmidt condensation of benzaldehide with acetophenone and their derivatives, $p$-methylacetophenone, $p$-methoxyac etophenone, as well as $\mathrm{m}, \mathrm{p}$-dichloroacetophenone were done in base condition using $\mathrm{NaOH}$ catalyst based on Vogel methode. Chalcone was able to be synthesized by reacting benzaldehide and acetophenone, while chalcone derivatives, $4^{\prime \prime}$-methyl chalcone, 4"-methoxychalcone, $3^{\prime \prime}, 4^{\prime \prime}$-dichlorochalcone, were able to be synthesized by reacting benzaldehide and $\mathrm{p}$-methylacetophenone, $\mathrm{p}$-methoxyacetophenone, $\mathrm{m}, \mathrm{p}$-dichloroacetophenone, respectively.

Sodium hydroxide was used to increase rate of reaction. The rate of catalysis reaction will be faster than acid catalysis reaction, due to the formation of enolate anion in the base catalysis, that is more reactive than enol form that formed by acid catalysis. The general rection dan mechanism of the formation of chalcones and its derivatives were illustrated in Fig. 4 and 5 .

All the compounds gave a single spot in TLC analysis and possed the very sharp melting range, so 
they were concluded that the compounds were pure. Purity of the synthesis products were also proved by the melting range (under $2{ }^{\circ} \mathrm{C}$ ). The melting ranges of chalchone, $4^{\prime \prime}$-methylchalcone, $4^{\text {II }}$-methoxychalcone and $3^{11}, 4^{11}$-dichlorochalcone was $54.4-55.6{ }^{\circ} \mathrm{C}$ (lit. [9] 57.4$59.3^{\circ} \mathrm{C}$ ), $50.4-51.9^{\circ} \mathrm{C}$ (lit. [12] $50-51^{\circ} \mathrm{C}$ ), $107.6-108.2{ }^{\circ} \mathrm{C}$ (lit. [13] 107.7-108.6 ${ }^{\circ} \mathrm{C}$ ), and $115.8-118.1{ }^{\circ} \mathrm{C}$ (lit. [14] 116.4-118.1 ${ }^{\circ} \mathrm{C}$ ), respectively. After identification by spectroscopic methods, i.e., infrared spectroscopy, nuclear magnetic resonance as well as mass spectrometry, the structures could be confirmed.

The absorption band of carbonyl groups of benzaldehide, acetophenone, p-methylacetophenone, p-methoxyacetophenone, and m,p-dichloroaceto phenone in the UV region were shifted to the longer wavelengths after the carbonyl group was conjugated to a double bond in chalcone, 4"-methylchalcone, $4^{\prime \prime}$-methoxychalcone, as well as $3^{\prime \prime}, 4^{\text {II }}$-dichlorochalcone. It was proved that chalcones, 4"-methylchalcone,

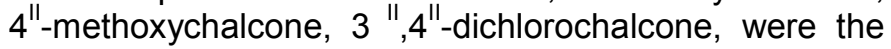
$\alpha, \beta$-unsaturated carbonyl compounds 6) [15].

Benzaldehide showed IR absorption at $1700 \mathrm{~cm}^{-1}$ indicating the presence of a carbonyl group $(>C=O)$, while acetophenone, p-methylacetophenone, p-methoxyacetophenone as wel as $\mathrm{m}, \mathrm{p}$-dichloroaceto phenone showed a band at 1681.8, 1685.7, 1670.2 and $1685.7 \mathrm{~cm}^{-1}$, respectively. The IR absorption frequency of a carbonyl $(>C=O)$ group of chalcones showed at $1658.7 \mathrm{~cm}^{-1}$, while chalcone derivatives, $4^{11}$-methylchalcone, 4"-methoxychalcone, $3^{\prime \prime}, 4^{\prime \prime}$-dichloro chalcone showed IR absorption of a carbonyl $(>C=O)$ group at 1658.78, 1651.07, and $1658.78 \mathrm{~cm}^{-1}$ respectively. It was proved that chalcone, $4^{\prime \prime}$-methylchalcone, $\quad 4^{\prime \prime}$-methoxychalcone, and $3^{\text {II }}, 4^{\text {II }}$-dichlorochalcone, were the $\alpha, \beta$-unsaturated carbonyl compounds.

Mass spectroscopy data were used to determine the molecular weight of each synthesized compound. Mass spectroscopy analysis was performed on the MS coupled GC with the injector temperature of $320^{\circ} \mathrm{C}$. The column temperature was set from $150{ }^{\circ} \mathrm{C}$, maintained for $5 \mathrm{~min}$ and then increased $10^{\circ} \mathrm{C} / \mathrm{min}$ to achieve $290{ }^{\circ} \mathrm{C}$. The temperature was kept on $290{ }^{\circ} \mathrm{C}$ for $31 \mathrm{~min}$ to allow the compound volatile, run through the column and the results of fragmentation could be separated based on the $\mathrm{m} / \mathrm{z}$ value.

Utami [9] has synthesized related chalcones compound i.e. 4"-methylchalcone, but using different reagents and synthesis method. However the structure elucidation results showed the same profiles. GC-MS spectrum of our synthesized product showed the same peak of molecular ion $\left(\mathrm{M}^{+}, \mathrm{C}_{15} \mathrm{H}_{12} \mathrm{O}^{+}\right)$as that's of Utami [9], on $\mathrm{m} / \mathrm{z}=208$. Completes results of the characterization of the synthesis products were described below.

\section{Chalcone (1), $\mathrm{C}_{15} \mathrm{H}_{12} \mathrm{O}$}

It was crystallized from ethyl alcohol as yellow precipitates $(0.5842 \mathrm{~g})$, yield $56.17 \%$, m.p. 54.4-55.6 ${ }^{\circ} \mathrm{C}$ (lit. [9] 57.4-59. ${ }^{\circ} \mathrm{C}$ ); Rf $=0.58$ (Benzene); the retention time of $\mathrm{GC}=8.117 \mathrm{~min}$.

UV-Vis $\left(\lambda_{\max }, \mathrm{CHCl}_{3}\right)=241$ and $313 \mathrm{~nm}$. IR spectrum $\left(U_{\max }, \mathrm{cm}^{-1}, \mathrm{KBr}\right)=1658.78(\mathrm{C}=\mathrm{O}$, str, ketone), 1604.77 ( $\mathrm{C}=\mathrm{C}$, str, alkene), $3062.7(=\mathrm{CH}$, str, alkene aliphatic and aromatic), 1496.76 ( $\mathrm{C}=\mathrm{C}$, str, aromatic). ${ }^{1} \mathrm{H}-\mathrm{NMR}(60 \mathrm{MHz}, \mathrm{CDCl} 3, \delta(\mathrm{ppm}))=8.25-$ $7.90\left(\mathrm{~m}, 3 \mathrm{H},=\mathrm{CH} \beta, \operatorname{Ar} 2^{\mathrm{Il}}, 6^{\mathrm{ll}}-\mathrm{H}\right) ; 7.90-7.30(\mathrm{~m}, 9 \mathrm{H}$, $=\mathrm{CHa}, \operatorname{Ar} 5^{\prime \prime}, 3^{\prime \prime}, 5^{\prime \prime}, 2^{\prime}, 6^{\prime}, 3^{\prime}, 5^{\prime}, 4^{\prime}-\mathrm{H}$,). Mass spectrum $(\mathrm{El}, \mathrm{m} / \mathrm{z})=208\left(\mathrm{M}^{+}, \mathrm{C}_{15} \mathrm{H}_{12} \mathrm{O}^{+}, 68.75 \%\right), 207(\mathrm{M}-1$, $\left.\mathrm{C}_{15} \mathrm{H}_{11} \mathrm{O}^{+}, 100 \%\right), 179\left(\mathrm{C}_{14} \mathrm{H}_{11}{ }^{+}, 51.69 \%\right), 165\left(\mathrm{C}_{13} \mathrm{H}_{9}{ }^{+}\right.$, $8.06 \%), 131\left(\mathrm{C}_{9} \mathrm{H}_{7} \mathrm{O}^{+}, 47.67 \%\right), 103\left(\mathrm{C}_{8} \mathrm{H}_{7}^{+}, 41.45 \%\right)$, $77\left(\mathrm{C}_{6} \mathrm{H}_{5}^{+}, 15 \%\right), 51\left(\mathrm{C}_{4} \mathrm{H}^{3+}, 25.41 \%\right)$.

\section{$4^{\prime \prime}$-Methylchalcone (2), $\mathrm{C}_{16} \mathrm{H}_{14} \mathrm{O}$}

It was crystallized from ethyl alcohol as yellow precipitates $(0.6256 \mathrm{~g})$, yield $56.36 \%$, m.p. 50.4-51.9 ${ }^{\circ} \mathrm{C}$ (lit. [12] 50-59 ${ }^{\circ} \mathrm{C}$ ); Rf $=0.67$ (benzene); the retention time of $\mathrm{GC}=9.996 \mathrm{~min}$.

UV-Vis $\left(\lambda_{\max }, \mathrm{CHCl}_{3}\right)=240$ and $314 \mathrm{~nm}$. IR spectrum $\left(\mathrm{U}_{\max }, \mathrm{cm}^{-1}, \mathrm{KBr}\right)=1658.78(\mathrm{C}=\mathrm{O}$, str, ketone), $1604.77(\mathrm{C}=\mathrm{C}$, str, alkene), $3024.38(=\mathrm{CH}$, str, alkene aliphatic and aromatic), 1496.76 ( $\mathrm{C}=\mathrm{C}$, str, aromatis), 2916.37 and 2862.36 (-CH3, str, aliphatic), 1450.47 (-CH3, bend, aliphatic). ${ }^{1} \mathrm{H}-\mathrm{NMR}(60 \mathrm{MHz}$, $\left.\mathrm{CDCl}_{3}, \delta(\mathrm{ppm})\right)=8.20-7.20\left(\mathrm{~m}, 11 \mathrm{H},=\mathrm{CH} \beta, \operatorname{Ar} 2^{\prime \prime}, 6^{\prime \prime}\right.$, $\left.=\mathrm{CHa}, \operatorname{Ar} 2^{\prime}, 6^{\prime}, 3^{\prime \prime}, 5^{\prime \prime}, 3^{\prime}, 5^{\prime}, 4^{\prime}\right) ; 2.45\left(\mathrm{~s}, 3 \mathrm{H}, \mathrm{CH}_{3}\right)$. Mass spectrum $(\mathrm{El}, \mathrm{m} / \mathrm{z})=222\left(\mathrm{M}^{+}, \mathrm{C}_{16} \mathrm{H}_{14} \mathrm{O}^{+}\right.$, 86.55\%), $221\left(\mathrm{M}-1, \mathrm{C}_{16} \mathrm{H}_{13} \mathrm{O}^{+}, 100 \%\right), 207\left(\mathrm{C}_{15} \mathrm{H}_{11} \mathrm{O}^{+}\right.$, 24.07\%), $179\left(\mathrm{C}_{14} \mathrm{H}_{11}{ }^{+}, 20.60 \%\right), 165\left(\mathrm{C}_{13} \mathrm{H}_{9}{ }^{+}, 4.06 \%\right)$, $131\left(\mathrm{C}_{9} \mathrm{H}_{7} \mathrm{O}^{+}, 33.61 \%\right), \quad 119\left(\mathrm{C}_{8} \mathrm{H}_{7} \mathrm{O}^{+}, 55.24 \%\right), 103$ $\left(\mathrm{C}_{8} \mathrm{H}_{8}{ }^{+}, 36.08 \%\right), \quad 91\left(\mathrm{C}_{7} \mathrm{H}_{7}^{+}, 58.84 \%\right), \quad 77\left(\mathrm{C}_{6} \mathrm{H}_{5}^{+}\right.$, $32.61 \%), 65\left(\mathrm{C}_{5} \mathrm{H}_{5}{ }^{+}, 30.74 \%\right), 51\left(\mathrm{C}_{4} \mathrm{H}_{3}{ }^{+}, 15.22 \%\right)$.

\section{4"-Methoxychalcone (3), $\mathrm{C}_{16} \mathrm{H}_{14} \mathrm{O}_{2}$}

It was crystallized from ethyl alcohol as yellow precipitates (1.0909 g), yield 91.76\%, m.p. 107.6-108.23 ${ }^{\circ} \mathrm{C}$ (lit. [13] 107.7-108.6 ${ }^{\circ} \mathrm{C}$ ); $\mathrm{Rf}=0.56$ (Benzene); the retention time of $\mathrm{GC}=11.992 \mathrm{~min}$.

UV-Vis $\left(\lambda_{\max }, \mathrm{CHCl}_{3}\right)=241$ and $319 \mathrm{~nm}$. IR spectrum $\left(\mathrm{U}_{\max }, \mathrm{cm}^{-1}, \mathrm{KBr}\right)=1651.07(\mathrm{C}=\mathrm{O}$, str, ketone), 1604.77 ( $\mathrm{C}=\mathrm{C}$, str, alkene), 3055.24 (=CH, str, alkene aliphatic and aromatic), 1573.91 and 1496.76 (C=C, str, aromatic), 2931.80 and $2839.22\left(-\mathrm{CH}_{3}\right.$, str, aliphatic), $1427.32\left(-\mathrm{CH}_{3}\right.$, bend, aliphatic), 1300-1100 $\left(\mathrm{C}-\mathrm{OCH}_{3}\right.$, stretch, eter). ${ }^{1} \mathrm{H}-\mathrm{NMR}\left(60 \mathrm{MHz}, \mathrm{CDCl}_{3}\right.$, $\delta(\mathrm{ppm}))=8.00-8.30\left(\mathrm{~d}, 1 \mathrm{H},=\mathrm{CH}_{\beta}\right) ; 7.80-7.40(\mathrm{~m}, 8 \mathrm{H}$, $\left.\operatorname{Ar} 2^{\prime \prime}, 6^{\prime \prime}-\mathrm{H},=\mathrm{CH}_{\alpha}, \operatorname{Ar} 2^{\prime}, 6^{\prime}, 3^{\prime}, 5^{\prime}, 4^{\prime}-\mathrm{H}\right), 7.20-6.90$ (d, $\left.2 \mathrm{H}, \mathrm{Ar} 3^{\mathrm{II}}, 5^{\mathrm{Il}}-\mathrm{H}\right), 3.90\left(\mathrm{~s}, 3 \mathrm{H}, \mathrm{OCH}_{3}\right)$. Mass spectrum $(\mathrm{El}, \mathrm{m} / \mathrm{z})=238\left(\mathrm{M}^{+}, \mathrm{C}_{16} \mathrm{H}_{14} \mathrm{O}_{2}^{+}, 100 \%\right), 237(\mathrm{M}-1$, $\left.\mathrm{C}_{16} \mathrm{H}_{13} \mathrm{O}_{2}^{+}, \quad 81 \%\right), \quad 223 \quad\left(\mathrm{C}_{15} \mathrm{H}_{11} \mathrm{O}_{2}{ }^{+}, 18.69 \%\right), 207$ $\left(\mathrm{C}_{15} \mathrm{H}_{11} \mathrm{O}^{+}, 10 \%\right), 135\left(\mathrm{C}_{8} \mathrm{H}_{7} \mathrm{O}_{2}^{+}, 77 \%\right), 131\left(\mathrm{C}_{9} \mathrm{H}_{7} \mathrm{O}^{+}\right.$, 
Table 1. Cytotoxic Activity of Chalcone Derivatives on Human Breast Cancer Cell Lines

\begin{tabular}{|c|c|c|c|c|c|}
\hline \multicolumn{2}{|r|}{ Structure } & Compound & $\mathrm{R}_{1}$ & $\mathrm{R}_{2}$ & $\mathrm{IC}_{50}(\mu \mathrm{g} / \mathrm{mL})$ \\
\hline \multirow{3}{*}{$\left.4^{\prime} \overbrace{3^{\prime}}^{5^{\prime}}\right|_{2^{\prime}} ^{6^{\prime}}$} & \multirow{3}{*}{ 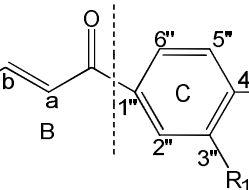 } & Chalcone & $\mathrm{H}$ & $\mathrm{H}$ & $9.58 \pm 0.74$ \\
\hline & & $4^{\prime \prime}$-methylchalcone & $\mathrm{H}$ & $\mathrm{CH}_{3}$ & $13.90 \pm 0.64$ \\
\hline & & $\begin{array}{l}\text { 4"-methoxychalcone } \\
3^{\prime \prime}, 4^{\prime \prime} \text {-dichlorochalcone }\end{array}$ & $\mathrm{Cl}$ & $\mathrm{Cl}$ & $\begin{array}{l}11.39 \pm 0.65 \\
24.10 \pm 1.03\end{array}$ \\
\hline
\end{tabular}

47.67\%), $103\left(\mathrm{C}_{8} \mathrm{H}_{7}^{+}, 41.45 \%\right), 77\left(\mathrm{C}_{6} \mathrm{H}_{5}^{+}, 55 \%\right), 51$ $\left(\mathrm{C}_{4} \mathrm{H}_{3}{ }^{+}, 12 \%\right)$.

\section{$3^{\prime \prime}, 4^{\prime \prime}$-Dichlorochalcone (4), $\mathrm{C}_{15} \mathrm{H}_{10} \mathrm{OCl}$}

It was crystallized from ethyl alcohol as yellow precipitates $(1.04 \mathrm{~g})$, yield $75.36 \%$, m.p. $115.8-118.1{ }^{\circ} \mathrm{C}$ (lit. [14] 116.4-118.1 ${ }^{\circ} \mathrm{C}$ ); $\mathrm{Rf}=0.64$ (methanol : chloroform $=9: 1)$; the retention time of $\mathrm{GC}=11.585 \mathrm{~min}$.

UV-Vis $\left(\lambda_{\max }, \mathrm{CHCl}_{3}\right)=241$ and $318 \mathrm{~nm}$. IR spectrum $\left(U_{\max }, \mathrm{cm}^{-1}, \mathrm{KBr}\right)=1658.78(\mathrm{C}=\mathrm{O}$, str, ketone $)$, $1604.77(\mathrm{C}=\mathrm{C}$, str, alkene), $3024.38(=\mathrm{CH}$, str, alkene aliphatic and aromatic), $1550.70(\mathrm{C}=\mathrm{C}$, str, aromatic). ${ }^{1} \mathrm{H}-\mathrm{NMR}\left(60 \mathrm{MHz}, \mathrm{CDCl}_{3}, \delta(\mathrm{ppm})\right)=8.25-8.14(\mathrm{~m}, 2 \mathrm{H}$, $\left.=\mathrm{CH}_{\beta}, \operatorname{Ar} 2^{\prime \prime}-\mathrm{H}\right)$; 7.90-7.30 (m, 8H, Ar 6"- $\mathrm{H},=\mathrm{CH}_{\alpha}, \operatorname{Ar} 5^{\mathrm{\prime \prime}}$, $2^{\prime}, 6^{\prime \prime}, 3^{\prime}, 5^{\prime \prime}, 4^{\prime}-\mathrm{H}$,). Mass spectrum $(\mathrm{El}, \mathrm{m} / \mathrm{z})=280(\mathrm{M}+4$, $6.5 \%) 278(\mathrm{M}+2,36 \%), 276\left(\mathrm{M}^{+}, \mathrm{C}_{15} \mathrm{H}_{10} \mathrm{OCl}_{2}{ }^{+}, 58.97 \%\right)$, $275\left(\mathrm{M}-1, \quad \mathrm{C}_{15} \mathrm{H}_{9} \mathrm{OCl}_{2}{ }^{+}, \quad 100 \%\right), 241 \quad\left(\mathrm{C}_{15} \mathrm{H}_{10} \mathrm{OCl}^{+}\right.$, $32.36 \%), \quad 145 \quad\left(\mathrm{C}_{6} \mathrm{H}_{3} \mathrm{Cl}_{2}{ }^{+}, \quad 22.69 \%\right), \quad 131 \quad\left(\mathrm{C}_{9} \mathrm{H}_{7} \mathrm{O}^{+}\right.$, $47.67 \%), 103\left(\mathrm{C}_{8} \mathrm{H}_{7}^{+}, 41.45 \%\right), 77\left(\mathrm{C}_{6} \mathrm{H}_{5}{ }^{+}, 15 \%\right), 51$ $\left(\mathrm{C}_{4} \mathrm{H}_{3}{ }^{+}, 25.41 \%\right)$.

\section{Cytotoxic activity}

The cytotoxic effect of chalcone and its derivatives was performed on HeLa cell lines by MTT assay. The advantage of this method was could be conducted fast and accurately, without using of radioisotope compound. The solvent used in this assay was DMSO, due to the low solubility of the test compounds in aqueous cell medium. Previous study about the influence of various cocentration of DMSO on the death of HeLa cell showed that concentration of DMSO up to $0.25 \% \mathrm{v} / \mathrm{v}$ did not affect the death of HeLa cell [16].

This colorimetric assay is based on the capacity of mitochondria succinate dehydrogenase enzymes in living cells to reduce the yellow water soluble substrate 3-(4,5-dimethylthiazol-2-yl)-2,5-diphenyl tetrazolium bromide (MTT) into an insoluble, colored formazan product which is measured spectrophotometrically. Since reduction of MTT can only occur in metabolically active cells, the level of activity is a measure of the viability of the cells. The color from yellow to purple was due to the break down of tetrazolium ring (Fig. 4). Absorbance of soluble Formazan was determined by ELISA reader at $550 \mathrm{~nm}$. The absorbance was correlated to live cells count. The death cells could not reduce MTT due to infunction of the enzyme. Fig. 5 illustrated the morphology of HeLa cell line after exposured of MTT.

Dose response curves constructed for MTT method between the range of $3.125-100 \mu \mathrm{g} / \mathrm{mL}$. Calculation of $\mathrm{IC}_{50}$ values was done using viability analysis. The results indicated that the antiproliferative effect strengthens with increase in the concentration of test compounds. From Table 1, it was observed that the highest cytotoxic activity was found with chalcone having $\mathrm{IC}_{50}$ value of $9.49 \mu \mathrm{g} / \mathrm{mL}$. Lower activity was showed by $3^{\prime \prime}, 4^{\prime \prime}$-dichlorochalcone with $\mathrm{IC}_{50}$ value of $24.26 \mu \mathrm{g} / \mathrm{mL}$.

The methyl and methoxy substituent at C- 4 " of aromatic ring directly bonded to enone ketone group ( $C$ region) decreaced the cytotoxic activity of chalcone, the parent compound. The lowering activity of methyl substituent was larger than that's of methoxy substituent. Substitution by chlor at $\mathrm{C}-3^{11}$ and $4^{11}$ of aromatic ring directly bonded to enone ketone group gave the largest effect on lowering cytotoxic activity of chalcone.

Test result of cytotoxic activity of chalcone synthesized by Utami [9] on HeLa cells line, gave the $I_{50}$ value of $9.77 \mu \mathrm{g} / \mathrm{mL}$. It was not significanly different from our result $(9.58 \mu \mathrm{g} / \mathrm{mL})$. Robinson et al. [1] also synthesized the same chalcone derivatives compounds, by the synthesis method based on the Claisen-Schmidt condensation reaction using alkaline catalyst $\mathrm{KOH}$. However, the cytotoxic activity of their product was conducted as in vitro cytotoxic activity on SVR endothelial cells. Utami [9] have tested the cytotoxic activity of synthesized chalcone derivatives compounds, which were the result of modification of the parent compound in the aromatic ring on the beta position of the ketone carbonyl group, on HeLa cells. Chalcone derivatives compounds in this study were the results of modification of the parent compound on the aromatic ring directly bound to the carbonyl group.

\section{CONCLUSION}

Chalcone and its derivatives, 4"-methylchalcone, $4^{\prime \prime}$-methoxychalcone, $3^{\prime \prime}, 4^{\prime \prime}$-dichlorochalcone, were able to be synthesized by alkaline condensation of acetophenone, p-methylacetophenone, p-methoxy acetophenone, m,p-dichloroacetophenone and benzaldehide. Cytotoxic activity on human breast 
cancer cell lines of chalcone was highest compared to its derivatives. It was concluded that methyl, methoxy as well as chlorine substution at $3^{\text {II }}$ and $4^{\text {II }}$ position decrease the cytotoxic activity of chalcone.

\section{ACKNOWLEDGEMENT}

The authors are grateful to Indonesian Ministry of Education for PEKERTI GRANT 2009-2011, Beta Andang Candranita, Endah sulistianingrum Diartanti, Devy Tri Hardiani and Atika Fi Nurjanah.

\section{REFERENCES}

1. Robinson, T.P., Hubbard, IV, R.B., Ehlers, T.J., Arbiser, J.L., Goldsmith, D.J., and Bowen, J.P., 2005, Bioorg. Med. Chem., 13, 4007-4013.

2. Mandge, S., Singh, H.P., Gupta, S.D., and Moorthy, N.S.H.N., 2007, Trends Appl. Sci. Res., 2, 1, 52-56.

3. Azad, M., Munawar, M.A., and Siddiqui, H.L., 2007. J. Appl. Sci., 7, 17, 2485-2489.

4. Oyedapo, O.A., Adewunmi, C.O., Iwalewa, E.O., and Makanju, V.O., 2008, J. Biol. Sci., 8, 1, 131-136.

5. Bandgar, B.P., Gawande, S.S., Bodade, R.G., Totre, J.V., and Khobragade, C.N., 2010, Bioorg. Med. Chem., 18, 3, 1364-1370.

6. Yarishkin, O.V., Ryu, H.W., Park, J.Y., Yang, M.S., Hong, S.G., and Park, K.H., 2008, Bioorg. Med. Chem. Lett., 18, 1, 137-140.
7. Srinivasan, B., Johnson, T.E., Lad, R., and Xing, C., 2009, J. Med. Chem., 52, 22, 7228-7235.

8. Echeverria, C., Santibañez, J.F., Donoso-Tauda, O., Escobar, C.A., and Ramirez-Tagle, R., 2009, Int. J. Mol. Sci., 10, 1, 221-231.

9. Utami, D., 2007, Thesis, Pharmacy, Graduate School, Universitas Gadjah Mada.

10. Vogel, A.I., 1959, A Text Book of Practical Organic Chemistry Including Qualitative Organic Analysis, Longmans, Green and Co Ltd, London, 716.

11. Ko, H-H., Tsao, L-T., Yu, K-L., Liu, C-T, and Wang, J-P., 2003, Bioorg. Med. Chem., 111,105-111.

12. Candranita, B.A., 2008, Synthesis of 4"-methylchalcone from $p$-Methylacetophenone and Benzaldehyde, Thesis, Pharmacy, Graduate School, Setia Budi University.

13. Nurjanah, A.F., 2008, Synthesis of 4 -methoxychalcone from $p$-Methoxyacetophenone and Benzaldehyde, Thesis, Pharmacy, Graduate School, Setia Budi University.

14. Diartanti, E.S., 2008, Synthesis of $3^{\text {II }}, 4^{\text {II }}$-methylchalcone, Thesis, Pharmacy, Graduate School Setia Budi University.

15. Solomons, 1997, Fundamentals of Organic Chemistry, $5^{\text {th }}$ ed., John Wiley \& Sons, Inc., 698700.

16. Harmastuti, N., 2005, Synthesis of p-Chlorochalcones Derivatives and Its Cytotoxycity Effects Against HeLa Cell, Thesis, Pharmacy, Graduate School, Universitas Gadjah Mada. 